\title{
LABORATORY-SCALE STUDY ON REACTIVE CONTAMINANT TRANSPORT IN SOIL BY MEANS OF ONE-DIMENSIONAL ADVECTIVE DISPERSIVE MODELS
}

\author{
Vincenzo Comegna, Antonio Coppola, Alessandro Comegna
}

\section{Introduction}

Contamination of soil with cadmium $(\mathrm{Cd})$ resulting from the application of sewage sludge and fertilizers, emissions from mining, smelting, and other industrial activities is widespread. This has led to long-term risks for soil fertility, ecosystem health, and ground water quality.

Cadmium is highly toxic to plants, animals and humans. In alkaline soils, the solubility of $\mathrm{Cd}$ is small because of precipitation of the solid phase. In acidic soils, however, the solubility of $\mathrm{Cd}$ is much greater and is controlled by adsorption on the clay minerals, oxides and organic matter [Mc Bride 1999]. The ecotoxicological significance of the environmental impact of $\mathrm{Cd}$ in soils is determined by the speciation and nature and intensity of its association with particular forms and solid-solution equilibria at the solid-water interface [Mc Laren 1998; Tenminghoff 1995]. It has long been accepted that total soil metal content alone is not a good measure of bioavailability and not a very useful tool to determine the potential risks associated with soil contamination [Peijnenburg 1997]. Mc Bride [1995] has pointed out that the real risk run in such environments is not so much the accumulation of contaminants in soil profiles, as the level of concentration reached by free ions in solutions, which in this form are bioavailable and toxic, with a mobility significantly affected by many complex processes such as organic matter decay, acid-base reactions, oxidation and reduction, ion competition and circulating solution flow along preferential pathways [Shuman 1991].

Prediction of the effect of contamination in soils as required in the past requires the use of empirical adsorption models for $\mathrm{Cd}$, based on cation exchange co-

Paper received 17.11.2010; accepted 24.01.2011

Vincenzo Comegna, full professor; ANTONIO Coppola, Associate professor; AlEssandro Comegna, researcher; Department for AgroForestry Systems Management (DITEC), Hydraulics Division, University of Basilicata, Potenza, Italy. Corresponding author: vincenzo.comegna@unibas.it, tel: 3293606229 fax: 09715429. efficients scaled to variation in the composition of soil solids and the solution phase [Alexandra 1992].

Only recently [Bajracharya 1996; Seuntjens 2002; Martin-Garin 2002] to study cadmium chemiodynamics, mathematical models have been used, based on adsorption equations, cation exchange combined with advective-dispersive equations. Development and parametrization of such models naturally assumes great importance. To date, parameters of such models, may be determined only by laboratory or field tests with miscible flow techniques [Jury 1991]. In this paper we examined the effect of soil solution composition and $\mathrm{pH}$ on the absorption and transport of cadmium through undisturbed and homogenized clay soil matrices, using batch and miscible dispacement techniques in the presence of $\mathrm{Ca}^{2+}$ and $\mathrm{Na}^{+}$salts of various ionic strength. The objective of the study was to provide a good understanding of the chemical mobility of cadmium for soil remediation purposes.

\section{Materials and methods}

\subsection{Measurement system project and execution}

A miscible flow experiment envisages a given solute transported by a water flow of known chemical characteristics passing through a bed consisting of a soil column of appropriate dimensions, while monitoring the ion concentration of the outflow solution at a set depth. For this purpose a high-performance flow cell was created (Fig. 1). The flow cell shown consists essentially of a soil column, a rain simulator, a vacuum unit and allows saturated and unsaturated flow experiments to be conducted.

The bottom end of the column support a nylon cloth of $25-\mu \mathrm{m}$ mesh wire with a bubbling pressure of $2.5 \mathrm{kPa}$. A bubble tower with a movable air entry tube allows the pressure potential h of water to be imposed at the bottom of the sample. The column is then equipped with a vertically installed bifilary TDR probe for measuring the water content $\theta$ and impedance $Z$ [Kachanosky 1992]; and with two tensiometers for measuring the water potential $h$. 
The laboratory-built TDR probe consists of two 5mm-diameter steel rods, $50 \mathrm{~mm}$ apart, $150 \mathrm{~mm}$ long extending from a perspex head enclosing a 1:1 matching ferrite balun [Spaans 1993] and is connected to the measuring device by a 2-m-long coaxial cable (RG58U) with a characteristic impedance of $50 \Omega$. Porous fritted glass tensiometers $(10 \mathrm{~mm}$ in diameter and with a bubbling pressure of $\approx 50 \mathrm{kPa}$ ) are inserted horizontally 5 and $15 \mathrm{~cm}$ down the soil column and are connected to pressure transuders. The leaching unit is completed by other basic components, namely: i) a Techtronix mod $1502 \mathrm{C}$ metallic TDR cable tester equipped with a RS232 interface (Techtronix, Ltd); ii) a personal computer for control, acquisition and data analisys; iii) a 50-needle (i.d. $0.6 \mathrm{~mm}$ ) rainfall simulator; iv) a peristaltic pump serving the simulator; and v) an automatic fraction collector to collect the effluent in a small fraction $\left(10-15 \mathrm{~cm}^{3}\right)$.

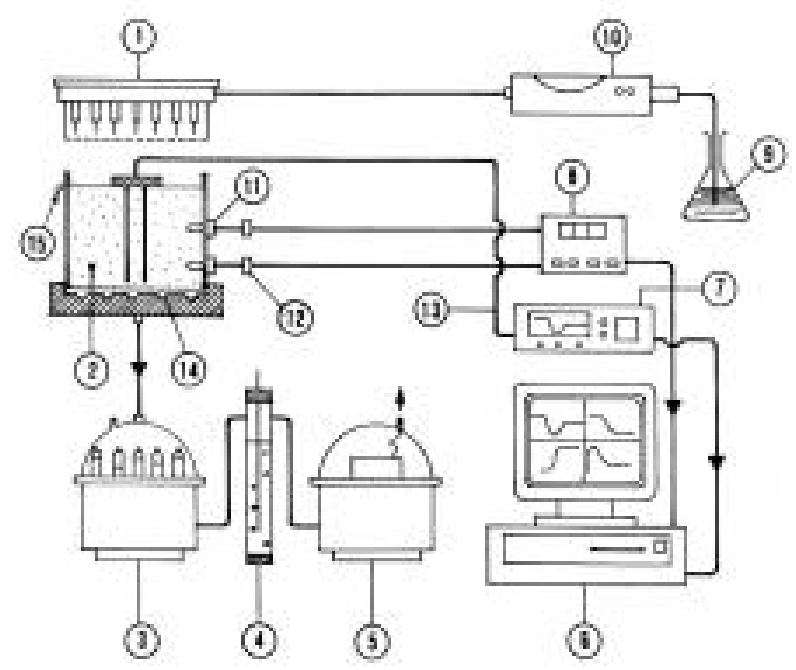

Fig. 1 - Experimental set-up: 1. rainfall simulator; 2. soil column; 3. fraction collector; 4. Mariotte regulator; 5. vacuum pump; 6. PC; 7. TDR tester; 8. multiplexer; 9. tracer container; 10. peristaltic pump; 11. tensiometer; 12 . pressure transducer, 13 coaxial cable; 14 nylon mesh; 15 overflow.

\subsection{Experiments to study the effect of the composition of soil circulating solution on cadmium transport}

Two soil monoliths $150 \mathrm{~mm}$ in diameter and 200 $\mathrm{mm}$ high were sampled from the Ap horizon of a soil of silty-clay loam texture on a farm, at Policoro in the region of Basilicata (Italy). The soil was pedologically classified as Fluvents Vertic. The main laboratorydetermined physical, chemical and hydraulic properties of the soil are reported in Tab 1, together with the properties of the horizon. The soil samples were arranged vertically on the measurement system, saturated from the bottom to determine hydraulic conductivity at saturation, and then undergoing a preliminary conditioning phase through feeding from the top of the flow system with solutions transporting mono$\left(\mathrm{NaNO}_{3}\right)$ and bivalent cations $\left(\mathrm{Ca}\left(\mathrm{NO}_{3}\right)_{2}\right)$ at different concentrations, respectively $0.02 \mathrm{M}$ and $0.2 \mathrm{M}$, until equilibrium was reached at $\mathrm{pH} 7$. At the end of this phase, the solutions were moved with stepwise feeding from another solution containing a fixed $\mathrm{Cd}\left(\mathrm{NO}_{3}\right)_{2}$ concentration $1 \mu \mathrm{mol} / \mathrm{l}$. During the leaching test to facilitate a free flow at the bottom of the columns, a zero pressure boundary condition was imposed and the leachate was periodically collected. The search for the $\mathrm{Cd}^{2+}$ ion was effected in the eluate with the differential pulse voltammetry method of Heyrovsky-Ilkovic [Bond 1980].

The adsorption isotherm was determined by the batch method: after homogenization, $2 \mathrm{~g}$ of air-dried sieved $(2 \mathrm{~mm})$ soil were equilibrated with various concentrations $(0-6 \mu \mathrm{mol} / \mathrm{l})$ of $\mathrm{Cd}\left(\mathrm{NO}_{3}\right)_{2}$ prepared in a $1: 10(\mathrm{~V} / \mathrm{V})$ suspension of soil in $0.01 \mathrm{M}$ of $\mathrm{Ca}\left(\mathrm{NO}_{3}\right)_{2}$. The suspensions were shaken for 24 hours at $20^{\circ} \mathrm{C} \pm 2{ }^{\circ} \mathrm{C}$. After separation by centrifugation at $10000 \mathrm{r} / 30^{\prime}$ the $\mathrm{Cd}^{2+}$ concentration was determined in the surnatant with the differential pulse voltammetry method. The quantity of cadmium adsorbed (S) was calculated as the difference between the initial concentration $\left(\mathrm{C}_{0}\right)$ and the concentration $\left(C_{e}\right)$ at equilibrium:

$S=\frac{C_{0}-C_{f}}{M} V$, in which $M$ is the mass of the adsorbent used and $V$ the volume of the solution.

The experiments to study the effect of $\mathrm{pH}$ and preferential flow on cadmium transport were conducted as follows: 1) the flow cell was filled with sieved soil (2 $\mathrm{mm})$, compacted and brought to soil bulk density of $1.3 \mathrm{~g} / \mathrm{cm}^{3} ; 2$ ) prior to starting the $\mathrm{Cd}$ soil contamination phase, the medium was conditioned using a $\mathrm{CaCl}_{2} 0.5 \mathrm{M}$ buffer solution, sequentially brought to pH 3, 5, 7 by adding $\mathrm{H}_{2} \mathrm{NO}_{3}$ and $\mathrm{NaOH}$, and then shifted with a solution of $\mathrm{Cd}\left(\mathrm{NO}_{3}\right)_{2} 1 \mu \mathrm{mol} / 1$.

\subsection{The ADE model}

The widespread use of ADE models in interpreting chemical transport phenomena in natural porous media is well documented [Jury 1991]. Herein we briefly recall that the advective-dispersive flow of a solute in an isotropic, homogeneous porous medium, affected by a permanent one-dimensional flow domain, in the absence of any sources and sinks of water and solutes can be described according to the following five dimensionless variables: i) relative concentration $C$; ii). relative distance $\mathrm{X}$; iii) Peclet number $\mathrm{P}$; iv) pore volume number $\mathrm{T}$ and $\mathrm{v}$ ) solute retardation factor $\mathrm{R}$. These variables are defined as follows:

$$
\begin{gathered}
T=\frac{v_{0} t}{L} \\
X=\frac{z}{L} \\
P=\frac{v_{0} L}{D}
\end{gathered}
$$




\begin{tabular}{|c|c|}
\hline USDA taxonomy & Fluvents Vertic \\
\hline Horizon & Ap \\
\hline Structure & Fine crumb-subgranularpoliedric \\
\hline SISS texture & Silty-loam \\
\hline Sand $\%$ & 25 \\
\hline Silt \% & 51 \\
\hline Clay $\%$ & 24 \\
\hline Apparent bulk density $\left(\mathrm{g} / \mathrm{cm}^{3}\right)$ & 1.29 \\
\hline Actual bulk density $\left(\mathrm{g} / \mathrm{cm}^{3}\right)$ & 2.63 \\
\hline Porosity & 0.510 \\
\hline Organic matter $\%$ & 4.34 \\
\hline $\mathrm{pH}\left(\mathrm{H}_{2} 0\right)$ & 7.65 \\
\hline $\mathrm{CEC}(\mathrm{cmol} / \mathrm{Kg})$ & 9.0 \\
\hline Hydraulic conductivity at saturation $(\mathrm{cm} / \mathrm{h})$ & 1.5 \\
\hline$\theta(\mathrm{h}=300 \mathrm{~cm})$ & 0.39 \\
\hline$\theta(\mathrm{h}=15000 \mathrm{~cm})$ & 0.15 \\
\hline
\end{tabular}

TABLE 1 - Physico-chemical properties of the soil in question.

$$
\begin{gathered}
C=\frac{\left(C_{c}-C_{i}\right)}{\left(C_{0}-C_{i}\right)} \\
R=1+\frac{\rho k}{\theta}
\end{gathered}
$$

in which $v_{0}=q / \theta\left(\mathrm{LT}^{-1}\right)$ is the effective velocity of the liquid phase, $q\left(\mathrm{LT}^{-1}\right)$ is the Darcian velocity, $\theta$ is the volumetric water content, $L(\mathrm{~L})$ is the length of the flow system, $z(\mathrm{~L})$ is the distance, $t(\mathrm{~T})$ is the time, $D$ $\left(\mathrm{L}^{2} \mathrm{~T}^{-1}\right)$ is the hydrodynamic dispersion coefficient, $C_{e}$ and $C_{i}\left(\mathrm{ML}^{-3}\right)$ are respectively the concentrations of outflow and initial solutions, $C_{0}\left(\mathrm{ML}^{-3}\right)$ is the inflow concentration, $\rho\left(\mathrm{ML}^{-3}\right)$ is the soil bulk density and $k$ $\left(\mathrm{L}^{3} \mathrm{M}^{-1}\right)$ is the distribution coefficient of the adsorption isotherm. Cadmium adsorption may be introduced into the equation using, for low concentrations, a linear isotherm of the type $S=k C$. Hence the convective-dispersive equation may be written as follows:

$$
R \frac{\partial C}{\partial T}=\frac{1}{P} \frac{\partial^{2} C}{\partial X^{2}}-\frac{\partial C}{\partial X}
$$

If all reactions are instantaneous, in the case of a linear adsorption isotherm, in a semi-infinite spatial domain and under a first-type boundary condition [van Genuchten 1986], an analytical solution for equation 6 is as follows:

$$
\begin{aligned}
& \frac{C}{C_{0}}(T)=\frac{1}{2} \operatorname{erfc}\left[\left(\frac{P}{4 R T}\right)^{\frac{1}{2}}(R-T)\right] \\
& +\frac{1}{2} \exp (P) \operatorname{vrc}\left[\left(\frac{P}{4 R T}\right)^{\frac{1}{2}}(R-T)\right]
\end{aligned}
$$

in which erfc is the complementary error function. Equation 7 was used to analyse the experimental BTCs measured on the columns in question since Peclet numbers $>4$ were found [Parlange 1992].

\section{Results and discussion}

To highlight the characteristic pattern of cadmium adsorption in the soil matrix, adsorption $S$ measured during the batch experiment (Fig. 2) is plotted against concentration $\mathrm{C}$ of cadmium in the solution.

The cadmium isotherm may be suitably described by the linear relation $\mathrm{S}=5.9 \mathrm{C}$. The distribution coefficient of the isotherm may be used to describe the split 


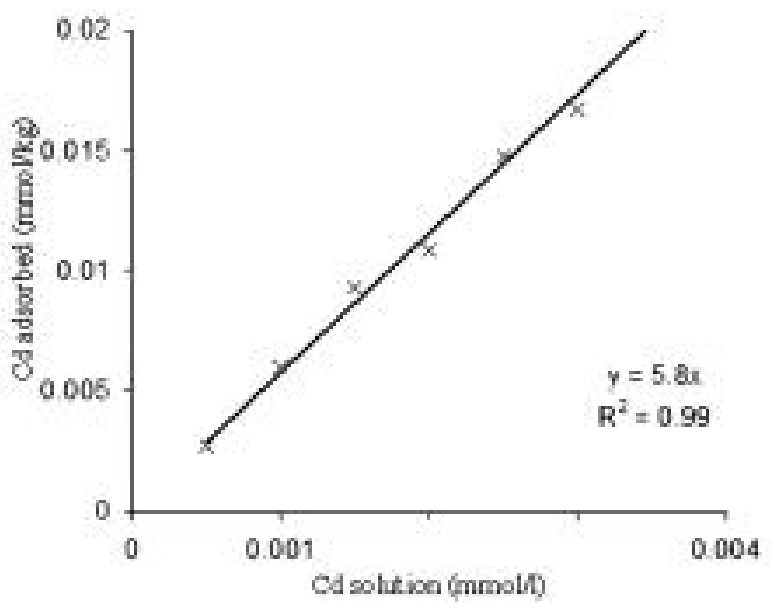

Fig. 2 - Adsorption isotherm.

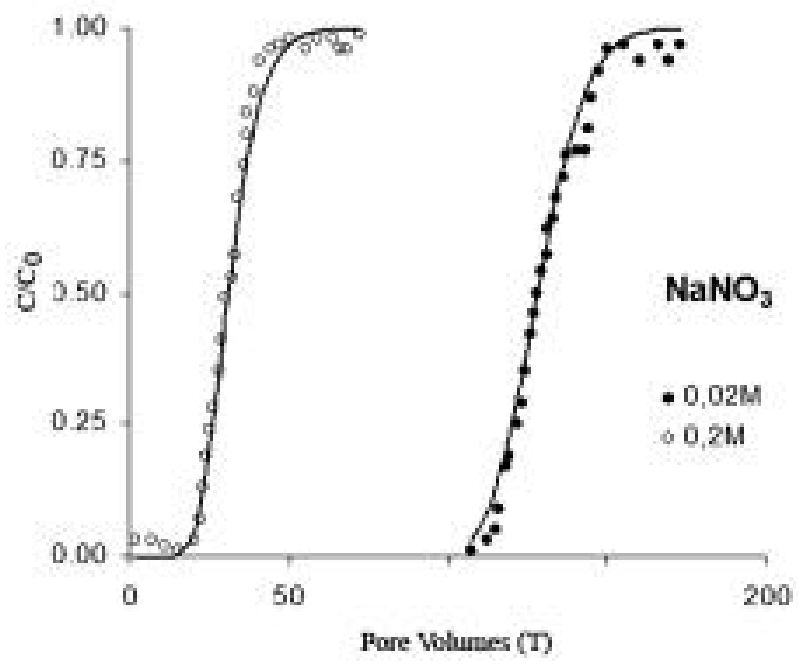

Fig. 3 - Breakthrough curves of cadmium measured (symbols) and calculated (line) for different sodium concentration levels.

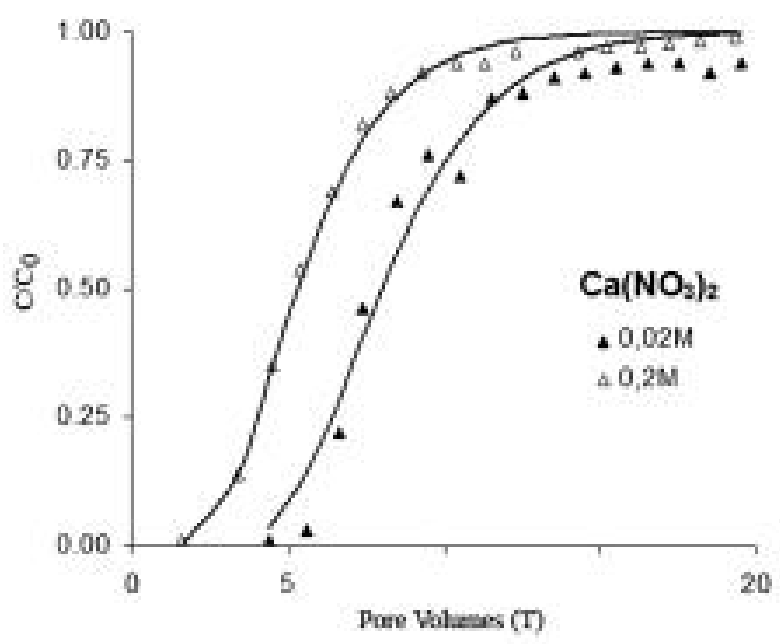

Fig. 4 - Breakthrough curves of cadmium measured (symbols) and calculated (line) for different calcium concentration levels. of the contaminant between the liquid and solid phases if the reactions determining the split are rapid and reversible and only if the isotherm is linear, as was ascertained in this case. This may further be explained by the presence of a circulating solution at low cadmium concentrations [Bajaracharya 1996].

From the analysis of the BTCs presented in Figures 3-4, the curves may be considered sigmoid, reflecting a type of transport consistent with the ADE model which entails a mobile liquid phase with miscible solute. The curves calculated by the ADE model were drawn with a continuous line. The model parameters were determined by an optimization procedure.

In general, where the BTCs for different $\mathrm{Na}$ concentrations are compared (Fig. 3), it may be noted that as the concentration increases, cadmium mobility increases about four-fold. By contrast, Figure 4 shows that the effect of the growth in $\mathrm{Ca}^{2+}$ concentration is less pronounced than that of the $\mathrm{Na}^{+}$ion. In this case, the more contained rise in $\mathrm{Cd}^{2+}$ mobility must presumably be attributed to the more significant competition of $\mathrm{Ca}^{2+}$, on adsorption sites of the matrix, even when $\mathrm{Ca}^{2+}$ is present in the solution at low concentrations.

In order to make a further useful comparison between the different breakthrough curves, reference was made to the retardation factor $\mathrm{R}$ to measure adsorption to be considered as the factor reducing $\mathrm{Cd}^{2+}$ mobility in the liquid phase flow. As regards the R, K, $\mathrm{D}$ and $\mathrm{P}$ values (Tab. 2), it may be noted that values of $\mathrm{R}$ and $\mathrm{K}$ are respectively $74 \%$ and $34 \%$ lower when the molar concentrations of $\mathrm{Na}$, and $\mathrm{Ca}$ increase from 0.02 to 0.2 . It was also observed that with the same ion concentrations (Fig. 5), $\mathrm{Cd}^{2+}$ mobility in the presence of the $\mathrm{Ca}^{2+}$ ion is one order of magnitude greater than the value observed in the presence of $\mathrm{Na}^{2+}$. This clearly indicates that the $\mathrm{Ca}^{2+}$ ion competes on adsorption sites in the matrix with the $\mathrm{Cd}^{2+}$ ion much more significantly than the $\mathrm{Na}$ ion.

Finally, as regards the conditioning of the circulating solution $\mathrm{pH}$, we observed that the measured breakthrough curves rotate counterclockwise as the pH decreases (Fig. 6). In particular: at pH 3 the retardation factor calculated was 29 and the mass balance close to 1; at $\mathrm{pH} 5$ the mass balance indicates that after 60 pore-volumes only $40 \%$ of $\mathrm{Cd}^{2+}$ was eluviated; at $\mathrm{pH} 7$, unlike what was observed on an undisturbed soil column, the tendency of $\mathrm{Cd}^{2+}$ to be totally adsorbed by the matrix was confirmed.

In this respect, it is worth recalling that other studies conclude that, in a neutral soil, $\mathrm{Cd}^{2+}$ is not very mobile. Reappraisal of these studies [Steenhuis 1994; Camobreco 1996; McBride 1997] suggests that the range of cases concerning the potential mobility of $\mathrm{Cd}^{2+}$ cannot yet be considered exhaustive since the tests in question used disturbed soil columns, actually neglecting the by-pass effects of the matrix on cadmium transport. 


\begin{tabular}{cccccc}
\hline \multicolumn{1}{c}{ Solutions } & $\mathbf{R}$ & $\mathbf{D}\left(\mathbf{c m}^{2} \mathbf{h}\right)$ & $\mathbf{K}(\mathbf{l} / \mathbf{k g})$ & $\mathbf{p H}$ & $\mathbf{P}$ \\
\hline $0.02 \mathrm{M} \mathrm{NaNO}_{3}$ & 128.0 & 0.51 & 50.2 & $7.0-7.2$ & 220.0 \\
$0.20 \mathrm{M} \mathrm{NaNO}_{3}$ & 31.0 & 3.64 & 11.9 & $6.4-6.5$ & 30.2 \\
$0.02 \mathrm{M} \mathrm{Ca}\left(\mathrm{NO}_{3}\right)_{2}$ & 8.0 & 2.43 & 2.6 & $7.2-7.3$ & 17.7 \\
$0.2 \mathrm{M} \mathrm{Ca}\left(\mathrm{NO}_{3}\right)_{2}$ & 5.3 & 9.40 & 1.7 & $6.2-6.5$ & 11.7 \\
\hline
\end{tabular}

TABLE 2 - R, D, K and P values calculated from the breakthrough curve.

\section{Conclusion}

Heavy metals are of particular concern because if they are immobile they then go on accumulating in the soil, thus polluting the soil environment. On other hand when mobile, they have the potential to degrade the quality of surface and groundwater even at relatively low concentrations.

This study demonstrated that Cd mobility in soil is

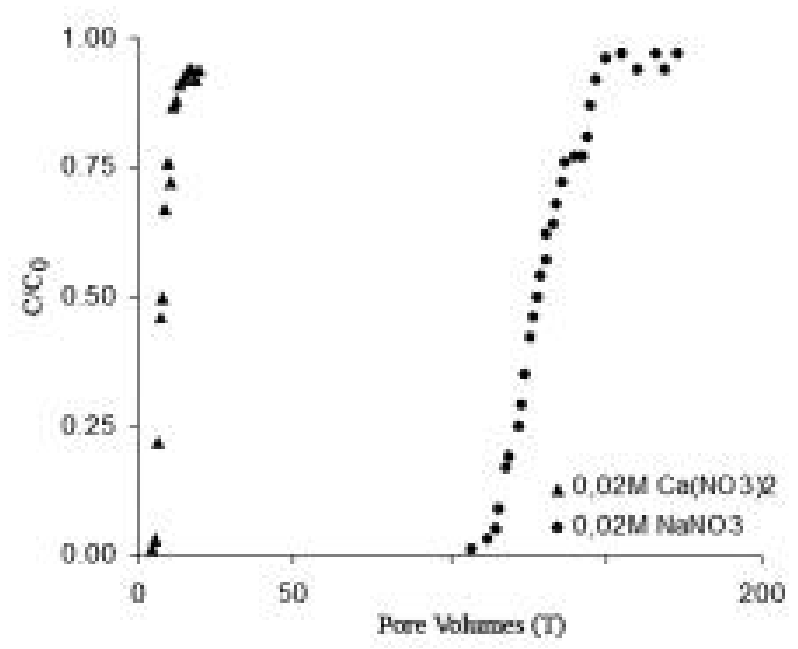

Fig. 5 - Breakthrough curve of cadmium according to ion valence.

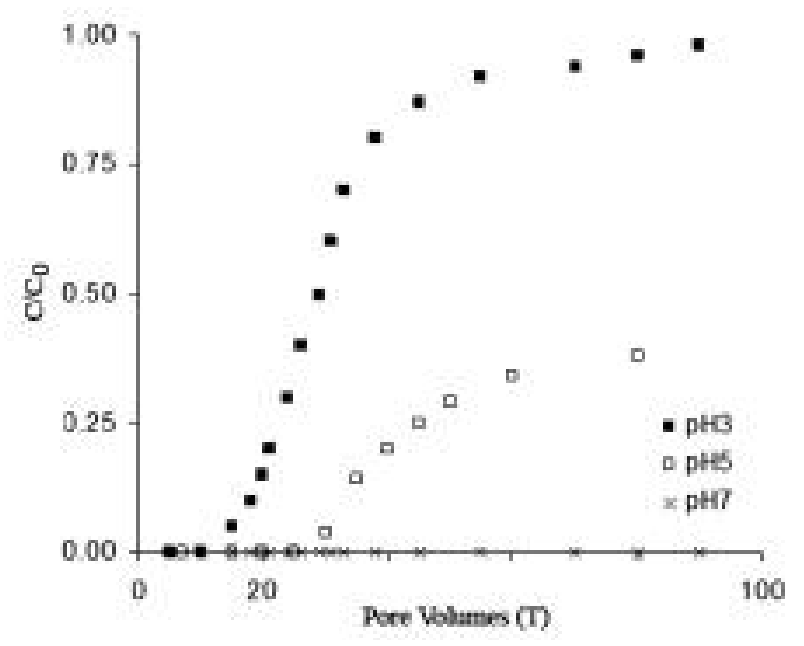

Fig. 6 - Breakthrough curves of cadmium as a function of $\mathrm{pH}$. strongly affected by the soil solution composition (ionic strength and type of cations), soil $\mathrm{pH}$ and the flow of circulating solution along preferential pathways. It is therefore crucial to elucidate the relationship between the total $\mathrm{Cd}$ content and the concentration in soil solutions in relation to major soil parameters.

The relation presented here between soil properties and Cd solubility allow us to derive the maximum tolerable total soil $\mathrm{Cd}$ content based on corrent groundwater quality standards as well as on estimates of potential consequences of land use changes (i.e. afforestation, soil tillage, soil fertilization and soil ammendements).

In general the results obtained suggest a possible use of ADE models already in concrete cases of soil remediation after degradation caused by intensive agricoltural management or by possible ecological accidents.

\section{References}

Alexandra E.B., Van der Zee S.E.A.T.M., A scaled sorption model validated at the column scale to predict cadmium contents in a spatially variable field soil. Soil Science, 1992, 154, 105-112.

Bajracharya K., Tran Y. T., Barry D. A. Cadmium adsorption at different pore water velocities. Geoderma, 1996, 73, 197-216.

Bond A. M. Modern polarographic methods in analytical chemistry, Marcel Dekker, Inc., 1980, NY.

Camobreco V.J., Richards B. K., Steenhuis T. S., Peverly J. H., McBride M. B. Movement of heavy metals through undisturbed and homogenized soil columns. Soil Sci., 1996, 161, 740-750.

Jury, W. A., Gardner W. R., Gardner W. H., 1991. Soil physics. Wiley, 2002, NY, $5^{\text {th }}$ ed.

Kachanosky R.G., Pringle F., Ward A. Field measurement of solute travel time using time domain reflectometry. Soil Sci. Soc. Am. J., 1992, 56, 47-52.

Martin-Garin A., Gaudet J. P., Charlet L., Vitart X. A dynamic study of the sorption and the transport processes of cadmium in calcareous sandy soils. Waste Management, 2002, 22, 201-207.

McBride, M. B. Toxic metal accumulation from agricultural use of sludge. Are USEPA regulations protective? J. Environ. Qual., 1995, 24, 5-18. 
McBride M. B., Richards B. K., Steenhuis T., Russo J. J., Sauvé S. Mobility and solubility of toxic metals and nutrients in soil fifteen years after sludge application. Soil Sci., 1997, 162, 487-500.

McBride M. B., Sauvé S., Hendershot W. Solubility control of $\mathrm{Cu}, \mathrm{Zn}, \mathrm{Cd}$ and $\mathrm{Pb}$ in contaminated soils. Eur. J. Soil Sci., 1997, 48, 337-346.

Mc Laren R.G., Backes C.A., Rate A.W., Swift R.S., Cadmium and cobalt desorption kinetics from soil clays: effect on sorption period, 1998, Soil Sci. Soc. Am., J., 62, 332-337.

Parlange J. Y., Starr J. L., van Genuchten M. Th., Barry D. A., Parker J. C. Exit condition for miscible displacement experiments. Soil Sci., 1992, 153:165-171.

Peijenburg W.J.G.M., Posthuma L., Eijsackers H.J.P., Allen H.E. Conceptual framework for implementation of bioavailability of metals for environmental management purposes. Ecotoxicol. Environ. Saf., 1997, 37, 163-172.

Seuntjens P., Mallants D., Simunek J., Patyn J., Jacques D. Sensitivity analysis of physical and chemical properties affecting field-scale cadmium transport in a heterogeneous soil profile. J. of Hydrol., 2002, 264, 185-200.

Shuman L. M. Chemical forms of micronutrients in soils. In J.J. Mortvedt (ed.) Micronutrients in agriculture. Soil Sci. Soc. Amer. Book series 4. Soil Sci. Soc. Amer., Inc., 1991, Madison, WI.

Spaans E.J.A., Baker J.M. Simple baluns in parallel probes for time domain reflectometry. Soil Sci. Soc. Am. J., 1993, 57, 668-673.

Steenhuis T., Boll J., Shalit G., Selker J. S., Merwin I. A. A simple equation for predicting preferential flow solute concentrations. J. Environ. Qual, 1994, 23, 1058-1064.

Temminghoff E.J.M., Van der Zee S.E.A.T.M., de Haan F.A.M., Speciation and calcium competition effects on cadmium sorption on sandy soil at vaarious pHs. Eur.J.Soil Sci., 1995, 46, 649-655.
Van Genuchten R. Th and Wierenga P. J. Solute dispersion coefficient and retardation factors. In A. Klute (Ed.) Methods of soil analysis. Part $1^{\text {st }}$ and $2^{\text {nd }}$ Ed. Agronomy, 1986, 9, 1025-1054.

\section{SUMMARY}

We measured adsorption and transport of cadmium (Cd) in the presence of $\mathrm{Ca}^{2+}$ and $\mathrm{Na}^{+}$salts of varying ionic strengths and $\mathrm{pH}$ by using batch and miscible displacement experiments, carried out on undisturbed and homogenized soil columns. A fluvent-vertic soil was used in this study. In the column experiment a clear effect of ionic strength on breakthrough curves (BTCs) of $\mathrm{Cd}^{2+}$ was observed when the $\mathrm{Na}^{+}$concentration was increased from 0.02 to $0.2 \mathrm{M}$. The effect of increasing the $\mathrm{Ca}^{2+}$ concentration on $\mathrm{Cd}^{2+}$ absorption and transport was relatively less pronounced than that recorded for the $\mathrm{Na}^{+}$solution. At low $\mathrm{pH}$ values, $\mathrm{H}^{+}$ions competed strongly with $\mathrm{Cd}^{2+}$ ions and, at a high $\mathrm{pH}$, precipitation was the main process taking place for $\mathrm{Cd}^{2+}$ sorption. The reliability of the advection-dispersion equation (ADE) was tested. When implemented within the least-squares method, the model produced a sufficiently precise space-time distribution of $\mathrm{Cd}^{2+}$ ion concentrations. The results of this study demonstrated also, that laboratory leaching experiments, when performed on homogenized soil columns, can greatly underestimate $\mathrm{Cd}^{2+}$ ions transport in the field and that preferential flow can increase the mobility and velocity of cadmium movement to the groundwater.

Keywords: sorption, ionic strength, $\mathrm{pH}$, miscible displacement, $\mathrm{Cd}^{2+}$ mobility. 